\title{
Soket Kontraktur Orbita: Definisi, Penyebab dan Klasifikasi
}

\section{Contracted Socket of Orbita: Definition, Causes, and Classification}

\author{
Debby Shintiya $D^{1}$, Diana Lyrawati \\ ${ }^{1}$ Laboratorium IImu Kesehatan Mata Rumah Sakit Umum Dr. Saiful Anwar Malang \\ ${ }^{2}$ Laboratorium Farmasi Fakultas Kedokteran Universitas Brawijaya Malang
}

\begin{abstract}
ABSTRAK
Soket anoftalmia (SA) lebih sering disebut sebagai anoftalmos atau anoftalmia didefinisikan secara klinis sebagai tidak adanya bola mata di dalam rongga orbita. Prevalensi anoftalmia sebesar 0,3 per 100.000 kelahiran. Berkurangnya volume SA disebut sebagai soket kontraktur (SK), pada keadaan ini soket tidak dapat menahan protesa. Protesa yang sulit atau tidak terpasang pada soket dengan tepat dan nyaman akan menimbulkan masalah kosmetik bagi penderita. Penyebab SK dapat kongenital atau didapat (acquired). Pengklasifikasian SK sangat penting dilakukan untuk menentukan protesa dan teknik operasi rekonstruksi yang sesuai. SK diklasifikasikan sesuai derajat keparahannya dari derajat ringan (1) sampai dengan derajat berat (5). Pada derajat 5 terdapat hilangnya semua fornik disertai adanya rekurensi kontraktur yang terjadi setelah dilakukan operasi rekonstruksi yang tidak berhasil dalam 1 tahun terakhir. Hal ini menunjukkan kegagalan rekonstruksi soket yang dilakukan.
\end{abstract}

Kata Kunci: Soket anoftalmia, soket kontraktur, protesa, rekonstruksi soket

\section{ABSTRACT}

Anophthalmic socket, also known as anophthalmos, is clinically absence of eyeball in the orbital. The prevalence of anophthalmos is 0,3 per 100,000 birth. The volume reduction in anophthamic socket is called contracted socket, is a condition which Anophthalmic socket cannot support the prosthesis. The ocular prosthesis that is not appropriately fitted resulting cosmetic problems to the patient. Contracted sockets can be caused by congenital and acquired. Contracted socket classification is very important to determine the appropriate prostheses and reconstruction surgical technique. The contracted socket is classified according to the severity of the tissue contraction from mild contracture (grade 1) to severe (grade 5). Grade 5 shows the loss of all fornices and recurrent contractures that occurred after a failed reconstruction surgery within a year. Grade 5 indicates socket reconstruction failure.

Keywords: Anophthalmic socket, contracted socket, prosthesis, socket reconstruction

Jurnal Kedokteran Brawijaya, Vol. 26, No. 4, Agustus 2011; Korespondensi: Debby Shintiya D. Laboratorium Ilmu Kesehatan Mata Rumah Sakit Umum Dr. Saiful Anwar Malang, Jl. Jaksa Agung Suprapto No. 2 Malang Tel. (0341) 341945 Email: shintdebby@gmail.com 


\section{PENDAHULUAN}

Orbital soket kontraktur yang selanjutnya akan disebut sebagai soket sontraktur (SK) merupakan masalah yang sering terjadi pada penatalaksanaan soket anoftalmia (SA). Hal ini akan menyebabkan sulitnya atau tidak dapat terpasangnya protesa pada soket sehingga menimbulkan masalah kosmetik bagi penderita (1-3). Menurut Adhikari et al SK terjadi pada 7,7\% SA. Dari prevalensi tersebut sebanyak 5,9\% kasus merupakan SK dari SA yang didapat, sedangkan SK dari SA kongenital sebesar 1,8\% (3).

Soket kontraktur dapat disebabkan banyak hal, antara lain trauma berat yang menyebabkan banyaknya jaringan konjungtiva yang hilang, infeksi yang parah, trauma kimia, prosedur operasi anoftalmia yang kurang tepat dan radioterapi (4). Pengklasifikasian SK sangat penting dilakukan untuk menentukan protesa dan teknik operasi rekonstruksi yang sesuai. Pada derajat ringan hanya didapatkan pendangkalan pada fornik, tetapi protesa masih dapat terpasang. Semakin besar derajat SK maka akan terjadi pendangkalan fornik yang lebih luas dan berat. Pada derajat yang paling berat dapat terjadi kehilangan seluruh fornik (5).

Penatalaksanaan SK sampai saat ini masih menjadi dilema dan tantangan bagi dokter mata. Mustarde melaporkan tidak lebih dari $50 \%$ kasus membaik dengan operasi (1). Hal ini dapat dicapai dengan perluasan area menggunakan graft seperti lemak dermal (6), membran mukosa mulut (7), membran amnion (8), palatum dan mukosa palatum $(7,9)$ atau kulit $(10)$. Keberhasilan rekonstruksi soket dicapai bila dapat dibentuk soket yang stabil sehingga dapat menahan protesa yang posisinya baik secara kosmetik dan mempertahankan fungsi kelopak mata (1).

Kajian pustaka ini dilakukan untuk membahas soket kontraktur orbita dari sisi batasan, penyebab dan klasifikasinya. Kajian dilakukan berdasarkan non systematic literature review yang dianalisis secara deskriptif naratif. Pemahaman yang tepat tentang diagnosis dan klasifikasi sangat penting sebagai dasar dalam menetapkan terapi terutama menentukan protesa dan teknik rekonstruksi yang adekuat.

\section{TINJAUAN PUSTAKA}

\section{Soket Anoftalmia}

Soket anoftalmia lebih sering disebut sebagai anoftalmos atau anoftalmia yang didefinisikan secara klinis sebagai tidak adanya bola mata di dalam rongga orbita (Gambar 1) dan secara anatomis sebagai tidak adanya jaringan ektodermal dan mesodermal. Prevalensi anoftalmia sebesar 0,3 per 100.000 kelahiran (3).

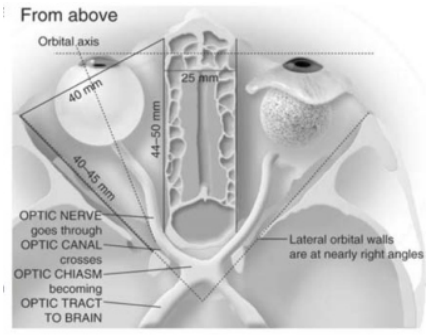

Gambar 1. Anatomi skematis mata normal (mata sebelah kiri) dibandingkan soket anoftalmia dengan implant dan protesa mata sebelah kanan (11)
Hubungan antara mata normal dengan orbita sangat penting dipahami (Gambar 2) didalam pengelolan anoftalmia. Anatomi mata normal ini sangat penting karena penampilan mata anoftalmia harus semirip mungkin dengan mata sebelahnya setelah pemasangan protesa (Gambar 3). Pembukaan antara kedua kelopak mata disebut sebagai fisura palpebra. Pembukaan kelopak mata dilakukan oleh otot levator palpebra superior (LPS) dan Muller's (11).

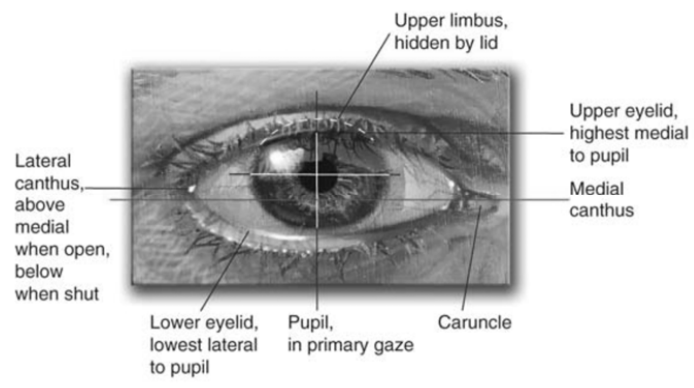

Gambar 2. Anatomi mata normal dalam dimensi skematis (11)

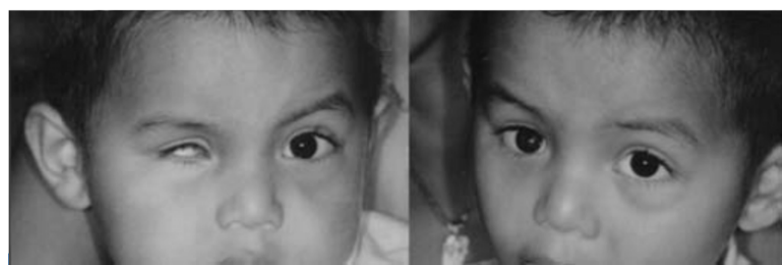

Gambar 3. Soket anoftalmia sebelum dan sesudah pemasangan protesa (11)

Pada SA sudah tidak didapatkan bola mata, sehingga didalam ruang orbita tinggal didapatkan jaringan orbita yang tertutupi oleh kapsul tenon dan konjungtiva serta kelopak mata. Permukaan soket ini dipertahankan tetap licin oleh permukaan konjungtiva agar pada saat pemasangan protesa tidak menimbulkan kelainan anatomis dan posisi (Gambar 4) (12).

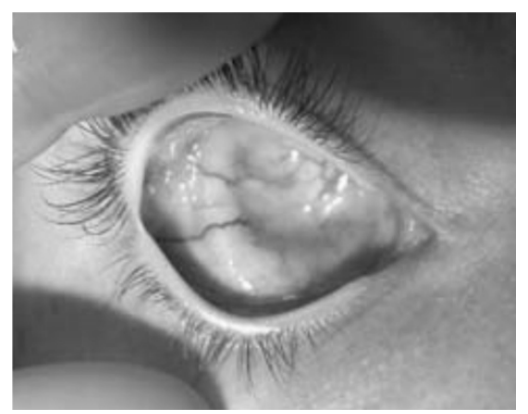

Gambar 4. Permukaan soket anoftalmia dipertahankan tetap licin oleh permukaan konjungtiva (12)

Konjungtiva adalah bagian terpenting dari permukaan mata yang merupakan membran mukosa (13). Lapisan di bawah konjungtiva disebut kapsul tenon yang merupakan 
struktur membran yang membungkus otot-otot ekstraokuli, bola mata dan saraf optikus (SO) membentuk muscle cone (11). Perubahan anatomi pada soket anoftalmia dapat merubah estetik dan pergerakan otot ekstra okuli akibat memendeknya otot tersebut meskipun volumenya masih tetap. Hal ini menyebabkan terbatasnya fungsi pergerakan otot tersebut, sehingga protesa juga tidak dapat bergerak seperti bola mata normal (14).

Soket anoftalmia dapat berupa kelainan kongenital maupun yang didapat (acquired). Penderita dengan SA kongenital primer biasanya hidup normal, tetapi pada yang sekunder biasanya ditemukan pada kasus penderita telah meninggal karena bayi lahir dengan aneucephaly. Pada anoftalmos consecutive (berturutan) biasanya disertai kelainan yang lain seperti Ulrich's syndrome, Golden Hart syndrome, Hemifacial microsomia, microphthalmos microstimia $(3,15,16)$.

Soket anoftalmia yang didapat adalah akibat dari operasi pengambilan bola mata oleh berbagai sebab. Operasi ini dapat berupa eviserasi, enukleasi dan eksenterasi. Enukleasi merupakan operasi pengambilan bola mata secara utuh, sedang eviserasi dilakukan dengan mengambil isi bola mata saja pada eksenterasi dilakukan operasi dengan mengambil seluruh isi orbita, sedang kelopak mata dapat tetap ditinggalkan atau turut diambil (4,11,17-20).

\section{Soket Kontraktur}

Soket kontraktur merupakan masalah yang sering terjadi pada SA dan pada keadaan ini soket tidak dapat menahan protesa. Hal ini akan menyebabkan sulitnya atau tidak dapat terpasangnya protesa pada soket sehingga menimbulkan masalah kosmetik bagi penderita. Kontraktur dapat terjadi pada fornik superior, inferior atau seluruh volume soket yang memberikan gambaran klinis berupa hilangnya daerah permukaan konjungtiva, jaringan ikat (scarring), atropi lemak orbita dan kontraktur atau pendangkalan fornik $(1-3,18)$.

Soket kontraktur dapat terjadi pada SA kongenital atau didapat (acquired). Pada satu studi disebutkan SK terjadi pada 7,7\% dari 1789 SA. Sebesar 5,9\% merupakan SK dari SA yang didapat, sedangkan SK dari SA kongenital sebesar $1,8 \%$. Pola demografis dari studi tersebut menunjukkan juga trauma pada laki-laki terjadi 2 kali lebih sering dibandingkan pada perempuan (3).

Studi yang kami lakukan di RSU Dr. Saiful Anwar Malang pada 1 Januari sampai dengan 31 Desember 2007 menunjukkan bahwa terdapat 10 kasus (32,25\%) SK dari 31 kasus SA. Studi juga mengidentifikasi bahwa kasus SK sebanyak 6 (60\%) ditemukan pada perempuan perempuan, rerata usia $32,6 \pm 10,18$ tahun, dengan rentang usia 16 sampai 46 tahun dan paling banyak mengenai usia 26 sampai 40 tahun (50\%). Interval terjadinya SK terbanyak adalah 5 tahun pasca pengambilan mata, yaitu pada $6(60 \%)$ penderita, $2(20 \%)$ penderita terjadi dalam interval 1-5 tahun dan 2 (20\%) penderita lainnya terjadi kurang dari 1 tahun (21).

Pada satu studi lain disebutkan SA kongenital yang disertai dengan SK biasanya datang berobat pada dekade ke 2 atau ke 3 karena menginginkan koreksi deformitas yang terjadi untuk penampilan kosmetik yang baik. Pada keadaan ini biasanya protesa sudah sulit dipasang karena apertura palpebra sangat sempit dan sudah terjadi kontraktur tulang orbita (22).

Patogenesis SK belum dapat dipahami secara menyeluruh. Faktor predisposisi SK diantaranya adalah trauma yang berat sampai terjadi enukleasi (termasuk trauma kimia atau luka bakar), penyembuhan luka yang kurang baik (berhubungan dengan vaskularisasi yang kurang baik), infeksi, penyakit sikatrik konjungtiva, trauma pasca enukleasi (misalnya radioterapi), tidak digunakan atau posisi yang kurang tepat pada penggunaan konformer/protesa dan tidak terdapat implan orbita $(12,23)$.

Faktor utama yang berpengaruh pada patogenesis SK adalah inflamasi dan fibrosis yang menyebabkan pemendekan konjungtiva (shortening of the conjunctiva) (24). Terkadang teraba massa keras di dalam soket orbita meskipun tidak dipasang implan orbita, massa yang teraba keras ini merupakan jaringan ikat sikatrik (fibrous cicatrix). Dapat juga terdapat simblefaron, konjungtivitis infeksi, keradangan konjungtiva yang lain atau jaringan ikat (scarring) konjungtiva $(12,26)$.

Rentang waktu antara terjadinya kontraktur atau pemendekan soket dengan dilakukannya operasi sebelumnya dapat bervariasi antara 2 bulan sampai 48 tahun, tetapi mediannya adalah 7,5 bulan. Sebanyak 2 per 3 bagiannya pernah mengalami operasi soket sebelumnya sebanyak 2 kali, sedangkan lama waktu operasi sebelumnya sekitar 6 bulan atau 1 tahun (2). Menurut studi yang dilakukan Kumar et al tentang komparasi penanganan SK dengan graf membran amnion dan mukosa menunjukkan terjadinya SK antara 8-10 tahun (27).

\section{Penyebab Soket Kontraktur}

Soket kontraktur dapat disebabkan banyak hal, antara lain trauma berat yang menyebabkan banyaknya jaringan konjungtiva yang hilang, infeksi yang parah, trauma kimia, atau prosedur operasi anoftalmia yang kurang tepat sehingga merubah anatomi, fisiologi, hemodinamik, kosmetik serta fungsi dari orbita, dan radioterapi $(4,19,23)$. Menurut Poonyathalang et al SK dan pendangkalan fornik dapat menyebabkan berkurangnya ruang untuk menahan protesa. Soket kontraktur merupakan akibat dari berbagai macam proses seperti adanya fibrosis dari injuri berat yang terjadi sebelumnya, ekstruksi implan, infeksi kronik dan kegagalan menggunakan protesa atau implan. Hilangnya jaringan orbita juga dapat terjadi akibat tidak baiknya teknik operasi yang dilakukan dengan diseksi luas terhadap jaringan orbita atau kerusakan berlebihan dari konjungtiva dan kapsul tenon serta dapat juga terjadi akibat operasi soket yang berulang kali (2).

Tabel 1. Penyebab soket kontraktur (2)

\begin{tabular}{ll}
\hline Kongenital & Didapat \\
\hline Anoftalmia & Radioterapi \\
Mikroftalmia & Trauma Kimia Basa \\
& Fraktur orbita \\
& Infeksi kronis terutama yang berhubungan dengan \\
& ekstruksi implan \\
& Kegagalan menggunakan protesa \\
& Hilangnya konjungtiva yang berlebihan saat enukleasi \\
\hline
\end{tabular}


Penyebab terbanyak SK adalah dari faktor yang didapat, seperti anoftalmia akibat infeksi, teknik enukleasi yang kurang tepat, protesa yang tidak terpasang baik $(58,8 \%)$. Penyebab kedua terbanyak adalah akibat kelainan kongenital (24\%). Trauma kimia, termal, radiasi dan reaksi obat merupakan penyebab ketiga terbanyak $(17,2 \%)$ (Tabel 2) (3)

Tabel 2. Penyebab terbanyak soket kontraktur (3)

\begin{tabular}{llcc}
\hline No & Penyebab Kontraktur & Jumlah & Prosentase \\
\hline $\mathbf{1}$ & Kesalahan teknik enukleasi/infeksi soket & 79 & 58,6 \\
$\mathbf{2}$ & sehingga tidak dapat dipasang protesa & 11 & 8 \\
$\mathbf{3}$ & Trauma Kimia & 7 & 5,1 \\
$\mathbf{4}$ & Tradioterapi & 4 & 2,1 \\
$\mathbf{5}$ & Reaksi obat (Steven Johnson Syndrome) & 3 & 2 \\
$\mathbf{6}$ & Kelainan Kongenital & 33 & 24 \\
& Total & 137 & 100 \\
\hline
\end{tabular}

Adanya infeksi atau keradangan dapat menyebabkan terjadinya SK ataupun SK berulang atau rekuren. Terapi medikamentosa pada keadaan tersebut dapat membantu agar tidak terjadi SK. Misalnya adanya konjungtivitis infeksi, blefarokonjungtivitis, atau infeksi soket yang lebih dalam harus diberikan terapi yang agresif dengan antibiotik topikal atau sistemik bila diperlukan, konformer soket walaupun kecil seharusnya tetap terpasang menggantikan protesa yang hilang atau terlepas dari orbita, konjungtivitis alergi pada soket anoftalmia memerlukan antihistamin topikal, dekongestan, antihistamin sistemik, cromolin, lodoxamide tromethamine atau kortikosteroid topikal atau sistemik $(12,28)$.

Perawatan protesa yang kurang baik juga dapat menjadi faktor penyebab terjadinya SK. Protesa sebaiknya dibersihkan setidaknya seminggu sekali, termasuk membersihkan deposit-deposit yang menempel. Setahun sekali atau dua kali protesa dihaluskan sehingga permukaannya licin dan lembut untuk mencegah terjadinya Giant Papillary Conjunctivitis (GPC) dan keradangan konjungtiva $(12,26)$.

\section{Klasifikasi Soket Kontraktur}

Pengklasifikasian SK sangat penting dilakukan untuk menentukan protesa dan teknik operasi rekonstruksi yang sesuai. Pada dasarnya okularis memiliki beberapa pilihan teknik dan peralatan yang dapat digunakan pada kasus SK, tetapi bagaimanapun untuk melengkapi pemilihan diperlukan pengkategorian yang tepat terhadap kondisi yang ada sehingga dapat memberikan gambaran yang lengkap tentang pemilihan jenis koreksi baik secara prostetik dan operasi (5).

SK diklasifikasikan sesuai derajat keparahannya sebagai berikut: (1) derajat 0: soket dengan konjungtiva yang sehat, fornik dalam dan terbentuk dengan baik (Gambar $5 A),(2)$ derajat 1: soket dengan karakteristik fornik inferior yang dangkal atau datar (Gambar 5B), (3) derajat 2: soket dengan hilangnya fornik superior dan inferior (Gambar $5 C)$, (4) derajat 3: soket dengan hilangnya seluruh fornik
(Gambar 5D), (5) derajat 4: soket dengan hilangnya seluruh fornik dan berkurangnya apertura palpebra baik horizontal maupun vertikal (Gambar 5E), (6) derajat 5: bila terjadi rekurensi kontraksi setelah rekonstruksi berulang (Gambar 5F) (5).
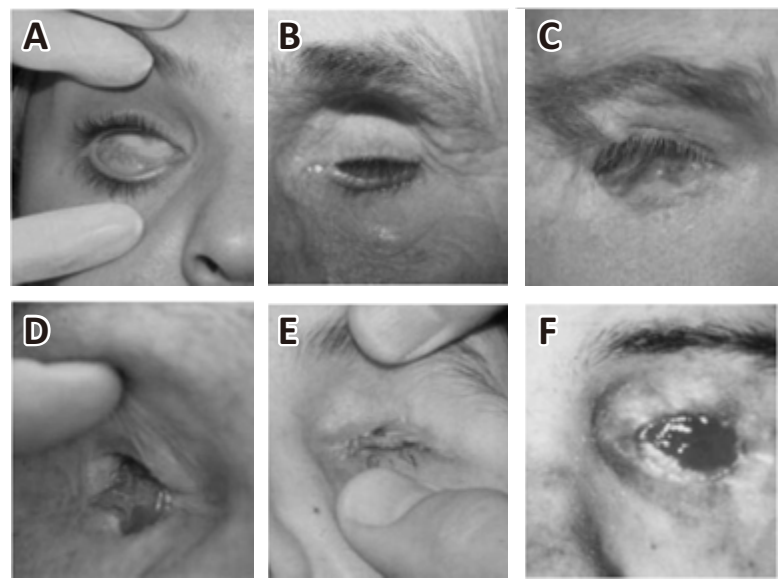

Gambar 5. SK grade 0 (A), grade 1 (B), grade 2 (C), grade 3 (D), grade 4 (E), grade 5 (F) (5)

Karakteristik derajat ringan memberikan gambaran pendangkalan pada 1 atau 2 fornik dan biasanya protesa masih dapat terpasang. Semakin besar derajat SK maka akan terjadi pendangkalan fornik yang lebih luas dan berat. Pada derajat 3 dan 4 terdapat gambaran yang sama yaitu hilangnya fornik, tetapi berbeda pada hilangnya apertura palpebra pada derajat yang lebih berat. Pada derajat yang paling berat yakni derajat 5 tidak terdapat perbedaan gambaran apertura, tetapi hanya dibedakan dari adanya rekurensi kontraktur yang terjadi setelah dilakukan operasi rekonstruksi yang tidak berhasil dalam 1 tahun terakhir. $\mathrm{Hal}$ ini penting dipertimbangkan karena dibutuhkan rentang waktu spesifik sebelum dilakukannya rekonstruksi yang berikutnya agar tidak terjadi kegagalan berikutnya yaitu sekitar 1 tahun $(5,25)$. Kasus SK yang terbanyak adalah derajat 4 dengan gambaran pengerutan konjungtiva berat dan bahkan sudah tidak ada jaringan konjungtiva, hilangnya fornik dan kedua kantus tampak membulat (3).

Pada beberapa literatur yang lain disebutkan pengklasifikasian SK yang lebih sederhana yaitu kontraktur soket ringan (mild) berupa pemendekan vertikal awal konjungtiva tarsalis dan konjungtiva palpebra, sehingga terjadi entropion sikatrikal, bulu mata masuk mengarah ke protesa, forniks masih adekuat menahan protesa pada tempatnya, kontraktur soket sedang (moderate) berupa kontraktur forniks palpebra superior dan inferior yang menyebabkan ketidakmampuan mempertahankan protesa yang berukuran pas pada tempatnya. Pada keadaan ini protesa tidak dapat berada tepat pada tempatnya, atau dapat dipakai protesa dengan ukuran lebih kecil dan kontraktur soket berat (severe) berupa pemendekan horizontal apertura palpebra dan membran mukosa serta kontraktur vertikal pada forniks, sehingga protesa tidak dapat dipasang sama sekali. Biasanya soket sangat dangkal hingga hanya sedalam ujung jari pemeriksa. Beberapa keadaan yang tergolong dalam 
kontraktur berat adalah pemendekan horizontal apertura palpebra dengan margo palpebra normal, pemendekan horizontal apertura palpebra dan mengkerutnya margo palpebra serta hilangnya forniks, atau bahkan kehilangan palpebra dan forniks secara kompleks $(4,12,15,17,29)$.

Dari kajian pustaka ini dapat disimpulkan bahwa SK merupakan keadaan berkurangnya volume soket anoftalmia (SA), sehingga soket tidak dapat menahan protesa dan menimbulkan masalah kosmetik bagi penderita. Penyebab SK dapat kongenital atau didapat (acquired). Penyebab yang didapat berupa simblefaron, defisit volume, hilangnya fornik inferior, ektropion, tidak digunakannya konformer dalam waktu yang lama, pseudoptosis, ketat atau tidaknya tendón kantus akibat kesalahan teknik operasi enukleasi, radiasi, infeksi, migrasi implan, dan operasi rekonstruksi soket berulang.

\section{DAFTAR PUSTAKA}

1. Mavrikakis I, Malhotra R, Shelley MJ, and Sneddon KJ. Surgical Management of the Severely Contracted Socket Following Reconstruction. Orbit. 2006; 25(3): 215-219.

2. Poonyathalang A, Preechawat P, Pomsathit J, and Mahaisaviriya P. Reconstruction of Contracted Eye Socket with Amniotic Membrane Graft. Ophthalmic Plastic and Reconstructive Surgery. 2005: 21(5): 359362.

3. Adhikari RK, Khazai $\mathrm{H}$, and Usha KD. Prospective Evaluation of Contracted Sockets. Kathmandu University Medical Journal. 2007; 5(3): 391-395.

4. Jones CA. Socket Surgery. In: Collin R (Ed). Fundamentals of Clinical Ophthalmology: Plastic and Orbital Surgery. London: American Medical Association; 2001; p. 89-97.

5. Webb MC. Issues in the Management of the Anophthalmic Socket: Clinical, Comfort, and Cosmetic. Ophthalmology Rounds. 2010; 8(1): 6.

6. Aguilar GL, Shannon GM, and Flanagan JC. Experience with Dermis-Fat Grafting: An Analysis of Early Postoperative Complications and Methods of Prevention. Ophthalmic Surgery. 1982; 13(3): 204209.

7. Lee AC, Fedorovich I, Heinz GW, and Kikkawa DO. Socket Reconstruction with Combined Mucous Membrane and Hard Palate Mucosal Grafts. Ophthalmic Surgery and Lasers. 2002; 33(6): 463-468.

8. Sangwan VS, Burman S, Tejwani S, Mahesh SP, and Murthy S. Amniotic Membrane Transplantation. British Journal of Ophthalmology. 2007; 55(4): 251256.

9. Wearne MJ, Sandy C, Rose GE, Pitts J, and Collin JR. Autogenous Hard Palate Mucosa: The Ideal Lower Eyelid Spacer. British Journal Ophthalmology. 2001; 85(10): 1183-7.

10. Karesh JW and Putterman AM. A Surgical Technique for the Successful and Stable Reconstruction of the Totally Contracted Ocular Socket. Ophthalmic Surgery. 1988; 19(3): 193-201.

11. Hughes MO. A Pictorial Anatomy of the Human
Penyebab kongenital dapat berupa mikroftalmos, cryptophthalmos, ankyloblepharon, koloboma kelopak mata, obliterasi fornik, ektropion kongenital dan lain sebagainya.

Pengklasifikasian SK sangat penting dilakukan untuk menentukan protesa dan teknik operasi rekonstruksi yang sesuai. Soket kontraktur diklasifikasikan sesuai derajat keparahannya sebagai berikut: derajat ringan (1 dan 2) adalah didapatkan pendangkalan pada 1 atau 2 fornik dan biasanya protesa masih dapat terpasang. Pada derajat sedang (3) terdapat gambaran hilangnya seluruh fornik, sedang derajat berat (4) terdapat hilangnya apertura palpebra. Pada derajat 5 tidak terdapat perbedaan gambaran apertura, tetapi hanya dibedakan dari adanya rekurensi kontraktur yang terjadi setelah dilakukan operasi rekonstruksi yang tidak berhasil dalam 1 tahun terakhir.

Eya/Anophthalmic Socket: A Review for Ocularists. Journal of Ophthalmic Prosthetics. 2007: 51-65

12. Roen JL and Stasior OG. Deformities of the Anophthalmic Socket. In: Steward WB (Ed). Surgery of the Eyelid, Orbit and Lacrimal System 3rd volume. San Fransisco: American Academy of Ophthalmology: 1995; p. 128-132.

13. Keefe KS, Milman T, Rodrigues MM, and Hidayat AA. Conjunctival and Corneal Pathology. In: Azar A (Ed). Principal and Practice of Ophthalmology 3rd edition. USA: Saunders; 2008; p. 3577-3608.

14. Detorakis ET, Engstrom RE, Straatsma BR, and Demer JL. Fungtional Anatomy of the Anophthalmic Socket: Insights from Magnetic Resonance Imaging. Investigative Ophthalmology and Visual Science. 2003; 44: 4307-4313.

15. Bayliss H, Shorr N, Tanenbaum M, and McCord CD. The Anophthalmic Socket: Evaluation and Management of Surgical Problems. In: McCord CD (Ed). Oculoplastic Surgery 2nd edition. New York: Raven Press; 1987; p. 425-429.

16. MacDonald IM, Tran M, and Musarella MA. Ocular Genetic: Current Understanding. Survey of Ophthalmology. 2004; 49(2): 159-196.

17. Tyers AG and Collin JR. Colour Atlas of Ophthalmic Plastic Surgery. 2nd edition. Oxford: ButterworthHeinemann: 2008; p. 237-273.

18. Garber PF and Della Rocca RC. Socket Reconstruction. In: Levine MR (ed). Manual of Oculoplastic Surgery 2nd edition. New York: Butterworth-Heinemann; 1996; p. 309-317.

19. Migliori ME. Enucleation, Evisceration, and Exenteration. In: Azar A (Ed). Principal and Practice of Ophthalmology 3rd edition. Saunders. USA: 2008; $p$. 3519-3528.

20. Nunery WR and Hetzler KJ. Enucleation and Eviseration. In: Speath GL (Ed). Ophthalmic Surgery: Principles and Practice 3rd edition. Philadelphia: Elsevier science: 2003; p. 501-503.

21. Lestari AT, Dewi DS, Sadono EG. Pattern and Management of Contracted Socket in Saiful Anwar Hospital Malang: A Retrospective Study. Kumpulan 
Abstrak Karya Tulis IImiah. Pertemuan IImiah Tahunan Perhimpunan Dokter Ahli Mata Indonesia. Makasar, 2008.

22. Naik MN and Raizada KB. Eyelid Switch Flap Technique for the Management of Congenital Anophthalmos Associated with Contracted Socket. Ophthalmic Plastic and Reconstructive Surgery. 2008: 22(6): 476479.

23. Zorab RA, Straus H, Denny M, Daniel J, and Garret TM. Basic and Clinical Science Course: Orbit, Eyelid and Lacrimal System. Section 7. San Fransisco: American Academy of Ophthalmology. 2010; p. 123-133.

24. Bajaj MS, Pushker N, Singh K K, Chandra M, and Ghose S. Evaluation of Amniotic Membran Grafting in the Reconstruction of Contracted Socket. Ophthalmic Plastic and Reconstructive Surgery. 2006; 22(2): 116120.

25. Kumar S, Sugandhi P, Arora R, and Pandey PK.
Amniotic Membran Transplatation versus Mucous Membran Grafting in Anophthalmic Contracted Socket. Orbit. 2006: 25: 195-203.

26. Petrelli RL. Management of the Contracted Eye Socket. International Ophthalmology. 1982: 5: 33-42.

27. Mody K. Fornix Reconstruction. In: Garg A (Ed). Oculoplasty and Reconstructive Surgery Made Easy. New Delhi: Jaypee Brothers Medical Publishers; 2009; p. 485-493.

28. Callahan MA and Callahan A. Correction of the Abnormal Soft Tissue Socket. In: Stewart WB (Ed). Ophthalmic Plastic and Reconstructive Surgery. San Fransisco: American Academy of Ophthalmology; 1984; p. 346-359.

29. Van der Meulen JC. Reconstruction of the Socket. In: Van der Meulen JC (Ed). Color Atlas and Text of Ocular Plastic Surgery. Barcelona: Mosby-Wolfe; 1996: p. 275-297. 